\title{
PERILAKU TIDAK PATUH ANAK USIA BATITA: STUDI DESKRIPTIF PADA KELUARGA MISKIN
}

\author{
Devi Oktari Harvens, Linda Primana, Rini Hildayani \\ Fakultas Psikologi, Universitas Indonesia \\ devi.oktari61@ui.ac.id
}

\begin{abstract}
ABSTRAK. Perilaku tidak patuh seringkali ditampilkan anak di usia batita dan dapat menjadi prediktor masalah perilaku pada anak. Perilaku tidak patuh merupakan suatu perilaku yang sengaja ditunjukkan oleh anak untuk tidak melakukan tindakan yang diminta oleh orangtua atau figur otoritatif lainnya. Penelitian ini bertujuan untuk mengetahui gambaran perilaku tidak patuh anak pada keluarga miskin. Perilaku tidak patuh, yakni mengabaikan, menolak, atau menunjukkan kemarahan, dilihat berdasarkan respon anak terhadap permintaan ibu dalam konteks merapikan mainan. Pendekatan kuantitatif dan kualitatif digunakan untuk menggambarkan perilaku tidak patuh pada anak. Hasil penelitian menunjukkan bahwa perilaku tidak patuh yang umum ditampilkan anak adalah mengabaikan permintaan ibu.
\end{abstract}

Kata kunci: perilaku tidak patuh, batita, keluarga miskin

ABSTRACT. Noncompliant behavior is a child's common response in toddlerhood and can be a predictor of child's behavior problem. Noncompliance is a behavior in which child purposely do not meet parents' or other authoritative figures' demands. This study aims to discover children's noncompliance behavior, specifically in low income family. Noncompliant behavior, i.e. passive noncompliance, overt resistance, or defiance, is assessed based on child's response in clean up task context. Quantitative and qualitative approach are used in this study to find the description of noncompliance behavior in children. The result shows that the most common response from children is ignoring mother's direction.

Keywords: noncompliance behavior, toddlerhood, family in poor

\section{PENDAHULUAN}

$$
\text { Memiliki anak yang patuh }
$$
merupakan dambaan sebagian besar orangtua. Kepatuhan anak menjadi salah satu isu perkembangan yang mulai terjadi di usia batita (toddlerhood). Kepatuhan (compliance) dapat didefinisikan sebagai kemampuan anak untuk menyesuaikan perilaku berdasarkan perintah atau keinginan pengasuh atau caregiver
(Edward \& Liu, 2002). Sebagai bentuk awal dari regulasi diri, kepatuhan mulai berkembang ketika anak memasuki usia 12 hingga 18 bulan. Pada usia ini, anak mulai memiliki kesadaran terhadap kehadiran tuntutan sosial dan mengembangkan kemampuan untuk memenuhi permintaan orangtua. Lebih lanjut, anak berperilaku patuh hanya saat diawasi dan diarahkan oleh orangtua atau figur otoritas 


\section{PSIKOVIDYA}

lainnya. Memasuki usia 24 bulan, anak memperoleh kontrol diri yang meliputi kemampuan untuk menunggu saat diminta dan mulai mampu meregulasi perilakunya, bahkan ketika tidak ada pengawasan dari orang lain. Pada usia 36 bulan, anak mulai mampu untuk meregulasi diri. Anak memiliki fleksibitas untuk memenuhi permintaan atau instruksi yang berubah dari satu situasi ke situasi lain (Feng, Hooper, \& Jia, 2017; Kochanska, Coy, \& Murray, 2001).

Perilaku tidak patuh pada anak mulai dapat terlihat ketika anak memasuki usia batita. Pada usia ini, anak seringkali berkata "tidak" terhadap berbagai permintaan atau instruksi dari orangtua atau figur otoritas lainnya (Charlesworth, 2017). Orangtua terkadang juga harus menghadapi kemarahan anak, seperti merajuk, berteriak, memukul, hingga menendang, sebagai bentuk penolakan anak terhadap permintaan orangtua yang diberikan kepada anak. Hal itu membuat orangtua kerap melabel anak sebagai anak yang tidak patuh (Maesyaroh, 2019; Niken, 2017; SayangiAnak, 2016; Zulhaqqi, 2013).

Memasuki tahap perkembangan usia batita, anak mulai menjadi sosok yang aktif untuk mengeksplorasi dunia sekitarnya. Keaktifan anak dalam mengeksplorasi tersebut ditunjang oleh perkembangan fisik-motorik anak yang semakin matang di tahap perkembangan ini (Newman \& Newman,
2012). Hal itu membuat anak menjadi lebih sering menghabiskan waktunya dengan melakukan kegiatan bermain. Lebih lanjut, anak menjadi lebih senang untuk menggunakan berbagai macam alat permainan yang menarik perhatiannya saat bermain sebagai salah satu cara untuk memahami dunia di sekitar dirinya.

Saat orangtua meminta anak untuk merapikan mainan setelah selesai digunakan, anak seringkali menolak permintaan tersebut, bahkan tidak jarang anak menunjukkan kemarahan. Pada usia batita, anak cenderung sulit untuk dapat memahami maksud dan tujuan dari instruksi yang diberikan kepada dirinya, termasuk saat diminta untuk merapikan mainan. Hal itu karena pada tahap usia batita, anak berada pada tahap perkembangan kognitif praoperasional (preoperational stage). Pada tahap perkembangan ini, anak memiliki keterbatasan cara berpikir yang bersifat egosentris. Egosentrisme adalah ketidakmampuan anak. untuk membedakan antara sudut pandang dirinya dan sudut pandang orang lain. Hal itu membuat anak cenderung berfokus pada sudut pandang yang dimilikinya dalam berpikir dan membuat keputusan (Santrock, 2011).

Kecenderungan anak untuk menolak permintaan orangtua juga terkait dengan keinginan anak untuk menjadi sosok yang memiliki kemandirian dan kontrol terhadap 


\section{PSIKOVIDYA}

Vol 24, No. 1, April 2020

dirinya. Dilihat berdasarkan teori perkembangan psikososial yang dikemukakan oleh Erik Erikson, anak pada usia batita berada pada tahap perkembangan autonomy versus shame and doubt. Pada tahap perkembangan ini, anak mulai memiliki pandangan bahwa dirinya memiliki kendali atas dunia di sekitarnya. Anak juga memiliki dorongan kuat untuk mencoba berbagai macam kegiatan, mengungkapkan keinginan, dan membuat keputusan secara mandiri. Dalam menunjukkan kemandirian dan kontrol diri yang dimiliki, anak cenderung menggunakan cara yang bersifat negatif (negativism), salah satunya ialah dengan berkata "tidak" terhadap berbagai macam permintaan atau instruksi dari orang lain (Charlesworth, 2017; Papalia \& Feldman, 2012).

Perilaku tidak patuh atau noncompliance merupakan perilaku yang dengan sengaja ditunjukkan oleh anak, baik secara aktif atau pasif, untuk tidak melakukan tindakan yang sesuai dengan permintaan orangtua atau pun figur otoritas lainnya (Kalb \& Loeber, 2003). Kochanska dan Aksan (1995) menyebutkan bahwa terdapat tiga bentuk perilaku tidak patuh yang ditampilkan oleh anak, yakni passive noncompliance, overt resistance, dan defiance. Pada perilaku passive noncompliance, anak menunjukkan perilaku tidak patuh dengan mengabaikan permintaan orangtua. Pada perilaku overt resistance - disebut juga sebagai self-assertive (BraungartRieker, Garwood, \& Stifter, 1997) -, anak menunjukkan penolakan terhadap permintaan orangtua dengan memberikan alasan atau melakukan negosiasi terhadap orangtua. Bentuk perilaku tidak patuh tersebut merupakan perilaku yang masih dapat diterima karena mencerminkan perkembangan kemampuan sosial dan kemandirian anak. Pada perilaku defiance, anak menunjukkan penolakan dengan disertai ekspresi emosi secara negatif, seperti merajuk, menangis, berteriak, menendang, dan tindakan agresif lainnya.

Kepatuhan anak di usia dini terhadap permintaan orangtua merupakan salah satu tanda pencapaian perkembangan regulasi diri anak secara emosi (Dennis, 2006). Hal itu dikarenakan untuk mematuhi permintaan orangtua, anak memerlukan kemampuan untuk menginisiasi, menghentikan, atau menyesuaikan perilakunya sesuai dengan standar yang dimiliki oleh orangtua (Kochanska, Coy, \& Murray, 2001). Perilaku patuh anak dapat dibagi ke dalam dua bentuk, yakni committed compliance dan situational compliance. Committed compliance dapat didefinisikan sebagai keinginan dan komitmen yang berasal dari dalam diri anak untuk memenuhi permintaan orangtua. Perilaku patuh ini ditandai dengan semangat yang ditampilkan dari dalam anak saat memenuhi 


\section{PSIKOVIDYA}

Vol 24, No. 1, April 2020

permintaan orangtua. Situational compliance adalah perilaku kooperatif yang ditunjukkan anak terhadap permintaan orangtua, namun perilaku tersebut tidak disertai dengan keinginan yang berasal dari dalam diri anak. Hal itu terlihat dari kecenderungan perilaku patuh anak yang mudah goyah dan perlu mendapatkan dukungan eksternal secara terusmenerus (Kochanska \& Aksan, 1995; Kochanska, Coy, \& Murray, 2001; Kok et al., 2013).

Kepatuhan yang ditampilkan anak dapat berdampak pada pencapaian akademik anak ketika memasuki usia sekolah. Studi yang dilakukan oleh Caughy, Mills, dan Owen (2018) menemukan bahwa kemampuan anak untuk mengikuti instruksi yang bersifat umum dapat memprediksi kemampuan membaca dan kemampuan matematis yang dimiliki anak. Kepatuhan anak juga dapat memberikan kesempatan yang lebih besar untuk berinteraksi dengan orang lain dan dapat menunjang perkembangan psikososial anak yang optimal. Anak yang mampu menyesuaikan perilaku sesuai dengan aturan yang berlaku saat bermain akan lebih popular dan lebih disukai oleh teman sebayanya (Elias \& Berk, 2002, dalam Charlesworth, 2017).

Di sisi lain, penolakan yang terusmenerus ditunjukkan anak, jika dibiarkan, dapat membuat anak mengalami kesulitan untuk mematuhi aturan dan tuntutan sosial, serta membuat anak berisiko memiliki perilaku bermasalah di tahap perkembangan berikutnya (Braungart-Rieker, Garwood, \& Stifter, 1997). Selain itu, perilaku tidak patuh yang terusmenerus dibiarkan dapat meningkatkan kecenderungan anak untuk melakukan tindakan agresif di kemudian hari. Studi yang dilakukan oleh Chen et al., (2002) menemukan bahwa perilaku tidak patuh yang ditunjukkan anak pada masa batita dapat meningkatkan perilaku agresif anak, baik secara verbal dan fisik, di tahap perkembangan selanjutnya. Lebih lanjut, perilaku tidak patuh yang disertai tindakan kasar - mengamuk atau menendang benda keras dan pecah belah - juga dapat berisiko menyebabkan luka fisik pada anak akibat dari tindakan tersebut (Kalb \& Loeber, 2003).

Perilaku tidak patuh pada umumnya ditampilkan oleh anak, terlepas dari status sosial ekonomi keluarga anak. Meski demikian, anak dari keluarga berpenghasilan rendah memiliki beragam faktor risiko yang dapat menghambat perkembangan anak. Huanqing Qi dan Kaiser (2003) menyebutkan tiga faktor risiko yang dimiliki oleh keluarga dengan penghasilan yang rendah. Faktor risiko pertama terkait dengan karakteristik anak. Faktor ini meliputi attachment security anak yang rendah, tempramen anak yang cenderung negatif, kelahiran prematur, tingkat kemampuan kognitif dan perkembangan 


\section{PSIKOVIDYA}

Vol 24, No. 1, April 2020

bahasa serta kemampuan sosial yang rendah, interaksi dengan teman sebaya yang bersifat negatif, dan jenis kelamin anak. Faktor kedua terkait dengan karakteristik orangtua, yang meliputi tingkat stres orangtua, tingkat pendidikan ibu, dukungan sosial yang rendah dan terbatas, dan cara disiplin yang cenderung keras. Faktor ketiga berkaitan dengan faktor sosial demografis. Faktor ini meliputi etnisitas, kondisi keluarga yang tidak stabil, konflik dalam keluarga, dan kekerasan dalam kelompok atau komunitas. Huanqing Qi dan Kaiser mengemukakan bahwa berbagai faktor risiko tersebut dapat meningkatkan kecenderungan terjadinya masalah perilaku pada anak.

Pada penelitian ini, peneliti berfokus pada anak yang berasal dari keluarga berpenghasilan rendah. Kelompok ini dipilih mengingat banyaknya faktor yang dapat menghambat pencapaian perkembangan anak secara optimal, termasuk perkembangan kepatuhan anak. Penelitian ini bertujuan memperoleh gambaran perilaku tidak patuh yang umum muncul pada anak usia batita, khususnya pada anak yang berasal dari keluarga miskin.

\section{METODE PENELITIAN}

a. Pendekatan dan Jenis Penelitian

Dalam melakukan penelitian ini, peneliti menggunakan pendekatan kuantitatif dan kualitatif. Pendekatan kuantitatif digunakan untuk melihat bentuk perilaku tidak patuh yang umum ditampilkan oleh subjek penelitian dalam konteks merapikan mainan ditinjau berdasarkan Child Compliance Coding yang dikembangkan oleh Kochanska dan Aksan (2008). Pendekatan kualitatif digunakan untuk melihat gambaran perilaku tidak patuh yang ditampilkan masing-masing subjek penelitian saat diminta merapikan mainan.

Berdasarkan tujuannya, penelitian ini termasuk ke dalam jenis penelitian deskriptif karena penelitian ini bertujuan untuk memperoleh gambaran mengenai suatu kondisi tertentu. Metode yang digunakan pada penelitian ini adalah observasi non-partisipatif (non-participant observation). Dalam observasi non-parsipatif, peneliti tidak terlibat dalam kegiatan yang dilakukan oleh subjek penelitian. Selama observasi berlangsung, peneliti berperan sebagai observer pasif. Observer bertugas mengamati serta mendengarkan hal-hal yang terjadi dalam kegiatan yang diobservasi dan menarik kesimpulan observasi tersebut (Kumar, 2011).

\section{b. Subjek Penelitian}

Penelitian ini dilakukan di salah satu perkampungan pemulung yang berada di daerah Menteng Atas, Jakarta Selatan. Pemilihan sampel yang menjadi subjek penelitian dalam penelitian ini diperoleh 
dengan menggunakan teknik bola salju (snowball technique).

Sebanyak 8 pasang ibu-anak (6 pasang ibu-anak laki-laki dan 2 pasang ibuanak perempuan) berpartisipasi dalam penelitian ini. Rata-rata usia ibu adalah 32,63 tahun $(\mathrm{SD}=12,05$; rentang usia 22 hingga 61 tahun) dan rata-rata usia anak adalah 2 tahun ( $\mathrm{SD}=0,76$; rentang usia 1 hingga 3 tahun).

Seluruh ibu yang berpatisipasi dalam penelitian ini bekerja sebagai ibu rumah tangga penuh waktu. Sebanyak 50\% $(\mathrm{n}=4) \mathrm{ibu}$ merupakan tamatan SMP/Sederajat, sedangkan sisanya tidak tamat sekolah $(\mathrm{n}=1)$ dan tamatan SMA/Sederajat $(n=3)$. Dari segi pendapat per bulan, seluruh subjek penelitian mengaku memiliki pendapatan $<$ Rp2.000.000, yang mana jika dilihat berdasarkan Angka Garis Kemiskinan di DKI Jakarta yakni sekitar Rp3.300.000, maka seluruh subjek penelitian dapat dikategorikan sebagai keluarga miskin (Ramli, 2019).

c. Prosedur Penelitian

Setiap pasang subjek penelitian datang ke lokasi penelitian secara bergantian. Lokasi penelitian berada di tengah perkampungan pemulung tempat mereka tinggal. Sesaat setelah subjek penelitian tiba, peneliti memberikan penjelasan singkat terkait tujuan dan gambaran kegiatan yang akan dilakukan selama proses penelitian berlangsung. Peneliti kemudian memberikan lembar persetujuan (informed consent) kepada ibu untuk ditandatangani. Peneliti selanjutnya meminta ibu untuk mengisi lembar data diri dan memberikan kesempatan kepada anak yang menjadi subjek penelitian untuk bermain dengan permainan yang disediakan. Setelah lembar data diri selesai diisi, peneliti memberikan instruks kepada ibu. Setiap pasangan ibu dan anak diminta untuk bermain bersama dengan menggunakan alat permainan yang telah disiapkan oleh peneliti untuk menstandarisasi tugas. Alat permainan yang disiapkan antara lain tiga buah buku cerita, dua set puzzle, 25 balok plastik, satu set peralatan bersih-bersih, satu set peralatan pertukangan, dan satu set peralatan memasak. Setelah waktu bermain habis yang ditandai dengan dua kali ketukan, ibu diminta untuk memberikan instruksi kepada anak untuk merapikan seluruh mainan ke dalam sebuah plastik yang telah disediakan. Waktu yang diberikan pada tiap anak untuk merapikan mainan adalah 10 menit. Setelah seluruh mainan selesai dirapikan, peneliti memberikan mainan bernilai Rp50.000 sebagai tanda terima kasih atas partisipasi para subjek penelitian.

\section{d. Teknik Pengumpulan Data}

Peneliti menggunakan tugas
merapikan mainan (cleanup task) yang
dikembangkan oleh Kochanska dan Aksan
$(2008)$ untuk melihat perilaku yang




\section{PSIKOVIDYA}

Vol 24, No. 1, April 2020

ditunjukkan oleh anak sebagai respon terhadap instruksi dari ibunya. Pada penelitian ini, peneliti menggunakan metode observasi dalam mengumpulkan data. Observasi dilakukan dengan cara menonton video berisi rekaman kegiatan bermain ibu-anak dan kegiatan anak merapikan mainan. Terdapat dua jenis data yang dikumpulkan dalam penelitian ini, yakni data kualitatif dan data kuantitatif. Data kualitatif diperoleh berdasarkan catatan tiap rater mengenai perilaku yang ditampilkan anak saat diminta untuk merapikan mainan oleh ibunya, sedangkan data kuantitatif berupa jumlah dari masing-masing bentuk perilaku patuh tidaknya anak saat merapikan mainan.

Data kuantitatif diperoleh berdasarkan koding perilaku yang mengacu pada Child Compliance Coding. Pada penelitian ini, koding dilakukan oleh tiga orang rater, termasuk peneliti. Dalam melakukan koding, peneliti membagi waktu observasi ke dalam 20 interval berdurasi 30 detik/interval. Masing-masing rater melakukan koding perilaku dengan melihat respon anak terhadap instruksi yang diberikan oleh ibu dalam tiap interval tersebut, yakni committed compliance, situational compliance, passive noncompliance, overt resistance, atau defiance. Contoh indikator dari masing-masing bentuk perilaku patuh dan perilaku tidak patuh dapat dilihat pada tabel di bawah ini:
Tabel 1. Contoh Indikator Perilaku

\begin{tabular}{|c|c|c|}
\hline Perilaku & $\begin{array}{l}\text { Bentuk } \\
\text { Perilaku }\end{array}$ & $\begin{array}{c}\text { Contoh } \\
\text { Indikator } \\
\text { Perilaku }\end{array}$ \\
\hline \multirow[b]{2}{*}{ Patuh } & $\begin{array}{l}\text { Committed } \\
\text { Compliance }\end{array}$ & $\begin{array}{l}\text { Anak terlihat } \\
\text { senang saat } \\
\text { memasukkan } \\
\text { mainan ke } \\
\text { dalam plastik }\end{array}$ \\
\hline & $\begin{array}{l}\text { Situational } \\
\text { Compliance }\end{array}$ & $\begin{array}{l}\text { Anak berhenti } \\
\text { merapikan } \\
\text { mainan saat } \\
\text { ibu tidak } \\
\text { memberikan } \\
\text { semangat } \\
\text { kepada anak }\end{array}$ \\
\hline \multirow{3}{*}{$\begin{array}{l}\text { Tidak } \\
\text { Patuh }\end{array}$} & $\begin{array}{c}\text { Passive } \\
\text { Noncompliance }\end{array}$ & $\begin{array}{l}\text { Anak terus } \\
\text { bermain } \\
\text { meski telah } \\
\text { diminta untuk } \\
\text { merapikan } \\
\text { mainan }\end{array}$ \\
\hline & $\begin{array}{c}\text { Overt } \\
\text { Resistance }\end{array}$ & $\begin{array}{l}\text { Anak berkata } \\
\text { "tidak" } \\
\text { dengan nada } \\
\text { bicara yang } \\
\text { normal }\end{array}$ \\
\hline & Defiance & $\begin{array}{c}\text { Anak } \\
\text { melempar } \\
\text { mainan saat } \\
\text { diminta untuk } \\
\text { merapikan } \\
\text { mainan }\end{array}$ \\
\hline
\end{tabular}

diskusi untuk melakukan penentuan akhir dari koding perilaku tiap segmen. Peneliti kemudian melakukan penjumlahan kemunculan respon dari masing-masing bentuk perilaku.

\section{e. Teknik Analisis Data}

Untuk melihat perbandingan skor total perilaku patuh dan perilaku tidak patuh 


\section{PSIKOVIDYA}

Vol 24, No. 1, April 2020

dari tiap subjek penelitian, peneliti melakukan penjumlahan terhadap terhadap masingmasing perilaku. Penjumlahan bentuk perilaku committed compliance dan situational compliance menghasilkan skor total perilaku patuh, sedangkan penjumlahan bentuk perilaku tidak patuh passive noncompliance, overt resistance, dan defiance menghasilkan skor perilaku tidak patuh. Rentang skor total yang dapat diperoleh tiap anak berkisar antara 0 hingga 20 untuk masing-masing perilaku patuh dan perilaku tidak patuh.

Selanjutnya untuk melihat gambaran bentuk perilaku tidak patuh yang umum ditunjukkan oleh seluruh subjek penelitian ini, peneliti melihat persentase dari kemunculan masing-masing bentuk perilaku tidak patuh. Persentase kemunculan masing-masing bentuk perilaku tidak patuh diperoleh dengan melakukan penghitungan sebagai berikut:

$$
\begin{aligned}
& \% \text { Kemunculan Perilaku } \\
& =\frac{\text { Jumlah perilaku tidak patuh }}{\text { Total kemunculan perilaku }} \times 100
\end{aligned}
$$

\section{HASIL DAN PEMBAHASAN}

\section{Hasil}

Berdasarkan skor total perilaku patuh dan skor total perilaku tidak patuh dari tiap subjek penelitian, diperoleh grafik perbandingan skor total perilaku patuh dan skor total perilaku tidak patuh sebagai berikut:

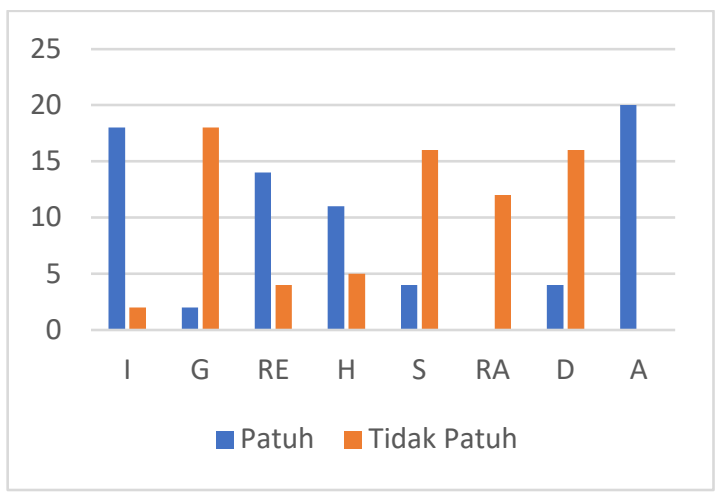

Gambar 1. Grafik Perbandingan Skor Perilaku Patuh dan Perilaku Patuh tiap Subjek Penelitian

Berdasarkan grafik di atas, dapat dilihat bahwa empat subjek penelitian memiliki skor total perilaku tidak patuh yang lebih tinggi dibandingkan dengan skor total perilaku patuh. Keempat subjek ini dapat dikategorikan sebagai anak yang tidak patuh, sedangkan keempat subjek lainnya dapat dikategorikan sebagai anak yang patuh.

Untuk melihat gambaran bentuk perilaku tidak patuh yang umum ditampilkan anak saat diminta merapikan mainan, peneliti melihat persentase kemunculan masingmasing bentuk perilaku tidak patuh. Persentase kemunculan masing-masing bentuk perilaku tidak patuh dapat dilihat sebagai berikut:

Tabel 2. Persentase Kemunculan Perilaku Tidak Patuh

Bentuk Perilaku Tidak

\begin{tabular}{ccc} 
Patuh & $\mathbf{N}$ & $\mathbf{\%}$ \\
\hline Passive Noncompliance & 41 & 56,16 \\
Overt resistance & 14 & 19,18 \\
Defiance & 18 & 24,66 \\
\hline Total & $\mathbf{7 3}$ & $\mathbf{1 0 0}$ \\
\hline
\end{tabular}


Tabel di atas menampilkan bentuk perilaku tidak patuh yang umum ditampilkn oleh para subjek penelitian saat diminta untuk merapikan mainan oleh ibu. Berdasarkan tabel di atas, perilaku passive noncompliance merupakan bentuk perilaku tidak patuh yang umum ditampilkan oleh subjek penelitian dengan nilai persentase sebesar 56,16\%. Perilaku tidak patuh lainnya yang cukup umum ditampilkan anak ialah defiance dengan besar persentase yakni $24,66 \%$.

$$
\text { Untuk memperoleh gambaran }
$$
perilaku tidak patuh yang ditunjukkan para subjek penelitian secara lebih mendalam dan konkret, peneliti melakukan pencatatan hasil observasi perilaku yang ditunjukkan oleh tiap subjek penelitian saat tugas merapikan mainan berlangsung. Adapun rangkuman hasil pencatatan observasi dari tiap subjek disajikan dalam tabel sebagai berikut:

Tabel 3. Rangkuman Perilaku Tidak Patuh tiap Subjek Penelitian

\begin{tabular}{ccl}
$\begin{array}{c}\text { Sub- } \\
\text { jek }\end{array}$ & $\begin{array}{c}\text { Bentuk } \\
\text { Perilaku Tidak } \\
\text { Patuh }\end{array}$ & $\begin{array}{c}\text { Contoh } \\
\text { Perilaku yang } \\
\text { Ditampilkan }\end{array}$ \\
\hline & & Subjek \\
& & cenderung \\
mengabaikan \\
dan terus \\
melanjutkan \\
& & kegiatan \\
I & Permain, \\
& Noncompliance & walaupun telah \\
& & diminta untuk \\
& & merapikan
\end{tabular}

\begin{tabular}{ll}
\hline & mainan oleh \\
ibunya. & \\
& Subjek \\
bernegosiasi \\
dengan ibu dan \\
Overt Resistance & meminta ibu \\
& untuk \\
& merapikan \\
& mainan. \\
\hline
\end{tabular}

Subjek cenderung menolak permintaan ibu dengan Defiance menunjukkan ekspresi emosi negatif, yakni merajuk, menangis, dan G melemparkan mainan.

Subjek mengabaikan permintaan ibu Passive dengan Noncompliance memperhatikan objek lain yang berada di sekitar dirinya.

Overt Resistance

Subjek menunjukkan perilaku tidak patuh dengan berkata "tidak" dengan nada bicara yang normal

RE

\section{Subjek} $\begin{array}{cl} & \text { melanjutkan } \\ \text { Passive } & \text { kegiatan } \\ \text { Noncompliance } & \text { bermain } \\ & \text { setelah ibu } \\ & \text { memberikan } \\ & \text { perintah untuk }\end{array}$

P-ISSN: 0853-8050 E-ISSN: 2502-6925 
merapikan mainan.

\begin{tabular}{|c|c|c|}
\hline $\mathrm{H}$ & $\begin{array}{c}\text { Passive } \\
\text { Noncompliance }\end{array}$ & $\begin{array}{l}\text { Subjek } \\
\text { cenderung } \\
\text { mengabaikan } \\
\text { permintaan ibu } \\
\text { untuk } \\
\text { merapikan } \\
\text { mainan dengan } \\
\text { melanjutkan } \\
\text { kegiatan } \\
\text { bermain. } \\
\text { Subjek juga } \\
\text { terlihat } \\
\text { mengalihkan } \\
\text { perhatian ibu } \\
\text { dengan cara } \\
\text { mengajak ibu } \\
\text { untuk } \\
\text { mengobrol } \\
\text { mengenai } \\
\text { mainan yang } \\
\text { seharusnya } \\
\text { dirapihkan. }\end{array}$ \\
\hline & Overt Resistance & $\begin{array}{l}\text { Subjek berkata } \\
\text { "tidak" } \\
\text { terhadap } \\
\text { permintaan } \\
\text { ibu. }\end{array}$ \\
\hline
\end{tabular}

Subjek terlihat menunjukkan penolakan dengan berkata "tidak" saat diminta untuk

Overt Resistance merapikan mainan oleh S ibu dan menyuruh ibu untuk melakukan tugas tersebut.

\section{RA}

RA

Defiance

Subjek cenderung melakukan hal
Passive Noncompliance

lain, seperti meminta untuk dipeluk atau menyusu kepada ibu, serta pergi menjauh setelah diingatkan ibu untuk merapikan mainan.

Subjek secara konsisten melanjutkan kegiatan bermain meski telah diminta untuk merapikan mainan dan diberikan contoh oleh ibu untuk melakukan hal tersebut.

Subjek merajuk dan menangis saat diingatkan kembali oleh ibu untuk merapikan mainan

Subjek cenderung mengabaikan perintah dari ibu untuk D $\begin{array}{cl}\text { Passive } & \text { merapikan } \\ \text { Noncompliance } & \text { mainan dengan }\end{array}$ cara melanjutkan kegiatan bermain dan mengajak ibu 
untuk ikut bermain.

Selain itu, anak juga cenderung mengajak ibu untuk membicarakan hal lain yang tidak berkaitan dengan tugas merapikan mainan.

Subjek sesekali terlihat melemparkan mainan sebagai

Defiance bentuk protes terhadap permintaan ibu.

\section{Pembahasan}

$$
\text { Hasil analisis skor perilaku }
$$
patuh/tidak patuh anak berdasarkan Child Compliance Coding menunjukkan bahwa sebagian besar anak masih cenderung menunjukkan perilaku tidak patuh saat diberikan tugas untuk merapikan mainan oleh ibunya, meski anak memiliki kemampuan untuk menampilkan perilaku yang diminta atau diharapkan oleh orangtua. Lebih lanjut, penelitian ini menemukan bahwa sebagian anak yang tergolong tidak patuh terhadap permintaan atau instruksi ibu memiliki skor perilaku tidak patuh yang tinggi dibandingkan dengan skor perilaku patuh. Hal itu mencerminkan kecenderungan anak yang dengan sengaja tidak memenuhi permintaan ibu.
Dilihat berdasarkan persentase kemunculan perilaku, bentuk perilaku passive noncompliance menduduki urutan tertinggi dan diikuti oleh perilaku defiance dan overt resistance secara berurutan.

Passive noncompliance adalah perilaku tidak kooperatif dan tidak menerima ekspektasi orangtua terhadap diri anak yang ditunjukkan oleh anak dengan cara mengabaikan instruksi atau permintaan orangtua (Kochanska \& Aksan, 2008). Pada penelitian ini, bentuk perilaku passive noncompliance yang ditunjukkan oleh anak antara lain terus melanjutkan kegiatan bermain, memperhatikan objek lain yang ada di sekitar anak, mengajak ibu untuk membicarakan hal lain yang tidak terkait dengan tugas merapikan mainan, meminta untuk disusui atau dipeluk oleh ibu, pergi menjauh dari mainan yang harus dirapihkan, dan mengajak ibu bermain.

Defiance adalah perilaku menentang yang ditunjukkan oleh anak terhadap permintaan orangtua, yang disertai dengan kemarahan (Kochanska \& Aksan, 2008). Contoh perilaku tersebut yang muncul dalam penelitian ini antara lain merajuk, menangis, dan melempar barang. Bentuk perilaku tidak patuh overt resistance adalah perilaku menolak permintaan orangtua yang ditunjukkan oleh anak dengan jelas dan tidak disertai dengan kesan melawan (non-aversive) (Kochanska \& Aksan, 2008). Pada penelitian ini, bentuk 


\section{PSIKOVIDYA}

Vol 24, No. 1, April 2020

perilaku overt resistance diwujudkan dengan cara menyuruh ibu untuk merapikan mainan ("ibu aje"). Bentuk lainnya adalah dengan berkata "tidak" dengan nada bicara yang normal saat ibu meminta anak untuk merapikan mainan.

\section{KESIMPULAN DAN SARAN}

\section{Kesimpulan}

Penelitian ini bertujuan memperoleh gambaran perilaku tidak patuh yang umum muncul pada anak usia batita, khususnya pada anak yang berasal dari keluarga miskin. Berdasarkan hasil penelitian, dapat disimpulkan bahwa sebagian anak masih cenderung menunjukkan perilaku tidak patuh terhadap permintaan ibu dalam konteks merapikan mainan. Dilihat dari bentuknya, perilaku passive noncompliance dan defiance merupakan bentuk perilaku tidak patuh yang paling umum dilakukan oleh anak saat diminta untuk merapikan alat permainan setelah kegiatan bermain berakhir.

\section{Saran}

Terdapat beberapa saran yang dapat dikemukakan terkait dengan hasil penelitian. Terkait dengan subjek penelitian, peneliti menyarankan untuk dilakukan sebuah program intervensi yang dapat membantu orangtua, khususnya ibu, dari keluarga miskin dalam menanggulangi ketidakpatuhan anak terhadap permintaan orangtua atau figur otoritas lainnya. Hal ini bertujuan untuk membantu orangtua untuk mengembangkan kepatuhan anak sejak usia dini serta mengurangi potensi masalah perilaku yang akan terjadi di tahap perkembangan berikutnya, mengingat banyaknya faktor risiko yang mengelilingi anak dari keluarga miskin.

Terkait dengan metode penelitian, peneliti menyarankan untuk memperbesar jumlah sampel yang menjadi subjek penelitian. Hal ini bertujuan untuk memperoleh gambaran perilaku tidak patuh anak pada keluarga miskin secara lebih komprehensif. Selain itu, penelitian selanjutnya juga dapat melihat hubungan perilaku tidak patuh dengan variabel lain yang terkait dengan faktor risiko pada keluarga miskin, sehingga dapat diperoleh penjelasan mengenai variabel yang membentuk perilaku tidak patuh pada anak.

\section{DISKUSI}

Hasil penelitian menunjukkan bahwa perilaku tidak patuh masih umum ditampilkan oleh anak sebagai bentuk respon terhadap permintaan ibu dalam konteks merapikan mainan. Lebih lanjut, bentuk perilaku tidak patuh yang umum ditampilkan anak adalah passive noncompliance dan defiance. Kedua bentuk perilaku tidak patuh ini dapat dikatakan sebagai bentuk perilaku yang tidak terampil (unskillful form). Hal itu karena pada kedua bentuk perilaku tidak patuh tersebut, anak menunjukkan ketidakmampuan anak dirinya 
dalam mengungkapkan keinginan dirinya. Lebih lanjut, kedua bentuk perilaku tidak patuh tersebut juga menunjukkan sikap permusuhan yang ditampilkan anak pada orangtua atau figur otoritas lainnya (Braungart-Rieker, Garwood, \& Stifter, 1997; Kuczynski \& Kochanska, 1990).

Di sisi lain, bentuk perilaku tidak patuh overt resistance dapat dikatakan sebagai bentuk perilaku yang terampil (skillful form). Hal itu karena pada bentuk perilaku tidak patuh ini, anak mampu mengungkapkan keinginannya dengan baik dan tenang, tanpa disertai ekspresi emosi negatif, seperti merajuk, menangis, hingga mengamuk. Selain itu, anak juga dapat menjelaskan dan memberikan alasan dari penolakan yang dikemukakannya

(Braungart-Rieker,

Garwood, \& Stifter, 1997; Kuczynski \& Kochanska, 1990).

Perilaku tidak patuh apabila terus dibiarkan dapat berpotensi meningkatkan potensi terjadinya masalah perilaku pada anak di tahap perkembangan berikutnya. Ketidakpatuhan anak merupakan salah satu prediktor dari kecenderungan anak untuk menunjukkan perilaku agresif, baik secara verbal maupun fisik, pada tahap perkembangan anak selanjutnya (Chen et al., 2002). Hal itu karena respon tidak patuh yang ditunjukkan oleh anak terhadap permintaan orangtua mengindikasikan kurang berkembangnya kemampuan anak dalam mengontrol dirinya (Kopp, 1982, dalam Chen et al., 2002).

Perilaku tidak patuh juga dapat menghambat perkembangan optimal anak terkait dengan aspek psikososial. Perilaku tidak patuh anak dapat menurunkan kemampuan anak untuk berpartisipasi dalam kegiatan terstruktur, seperti games, olahraga, dan kegiatan outing dengan teman sebaya. Lebih lanjut, ketidakpatuhan anak dapat menyebabkan anak sulit untuk berinteraksi dan membentuk hubungan yang bersifat positif dengan teman sebaya ataupun orang dewasa lainnya (Kalb \& Loeber, 2003).

Kondisi anak yang hidup dalam keluarga miskin dapat menjadi salah satu faktor yang berpotensi menghambat perkembangan perilaku patuh anak. Pada penelitian ini, para ibu yang menjadi subjek partisipan cenderung kurang terlibat secara aktif saat bermain dengan anak. Hal ini dapat mengindikasikan interaksi ibu dan anak yang kurang berkualitas. Dalam studi yang dilakukan Hikmatunnisa (2015) ditemukan bahwa ibu dan anak yang berasal dari keluarga dengan kategori miskin memiliki kualitas interaksi yang rendah. De Falco (2014) menjelaskan bahwa ibu yang memiliki status ekonomi yang rendah umumnya cenderung memberikan pengasuhan yang bersifat inkosisten, menghukum, dan koersif. Hal itu disebabkan oleh adanya tekanan emosi akibat 


\section{PSIKOVIDYA}

Vol 24, No. 1, April 2020

pendapatan yang kecil dan latar belakang kualitas pendidikan yang rendah. Selain itu, ibu dengan status sosial ekonomi rendah cenderung menggunakan arahan singkat dan kalimat yang bersifat mengontrol saat berkomunikasi dengan anak (Gurko, 2018). Lebih lanjut, ibu yang berasal dari keluarga miskin umumnya menggunakan cara yang mengganggu dan agresif terhadap anak saat memberikan perintah kepada anak, seperti mengintervensi dan mengulang-ulang permintaan tanpa memberikan kesempatan pada anak untuk menunjukkan respon patuh. Hal itu berpotensi meningkatkan kemunculan perilaku tidak patuh yang ditampilkan oleh anak (Grunzeweig et al., 2009).

Interaksi ibu dan anak merupakan faktor berperan penting dalam perkembangan moral anak (Kok et al, 2013), termasuk dalam perkembangan kepatuhan anak. Kochanska, Aksan dan Carlson (2005) menjelaskan bahwa pengasuhan yang bersifat responsif serta dukungan yang diberikan oleh orangtua selama berinteraksi dengan anak dapat membantu mengembangkan kemampuan anak untuk menaati peraturan secara sukarela.

Kualitas interaksi ibu-anak dapat memengaruhi perilaku patuh anak melalui tiga cara. Pertama, respon ibu terhadap kebutuhan atau permintaan anak menjadi contoh bagi anak mengenai norma yang berlaku dalam hubungan sosial. Melalui respon yang ditampilkan ibu saat memenuhi kebutuhan anak, secara tidak langsung anak belajar untuk menjadi sosok yang patuh dalam memenuhi permintaan dan instruksi dari ibu. Kedua, anak yang memiliki hubungan emosi yang bersifat aman (secure attachment) dengan ibu cenderung lebih mampu untuk meregulasi emosi dan perilakunya, sehingga lebih mampu untuk mematuhi aturan. Ketiga, hubungan timbal balik yang bersifat positif yang terjadi saat ibu dan anak berinteraksi membuat anak lebih cenderung mau untuk mematuhi permintaan ibu (Kok et al., 2013).

Penelitian ini dapat memberikan gambaran mengenai bentuk perilaku tidak patuh yang umum dilakukan oleh anak pada usia batita, khususnya anak yang berasal dari kelompok keluarga miskin. Meski demikian, jumlah sampel yang kecil menjadi salah satu kelemahan dari penelitian ini. Hal itu membuat hasil penelitian terkait tingkat perilaku tidak patuh anak sulit untuk digeneralisasikan dalam populasi penelitian, yakni anak batita pada keluarga miskin.

Terlepas dari keterbatasan yang dimiliki oleh penelitian ini, hasil penelitian ini dapat memberikan kontribusi yang berarti dalam mengetahui gambaran perilaku tidak patuh pada anak batita, khususnya pada keluarga miskin. Hasil penelitian dapat membantu menjelaskan masalah terkait kepatuhan yang menjadi salah satu isu 
perkembangan pada tahap perkembangan batita.

\section{DAFTAR PUSTAKA}

Braungart-Rieker, J., Garwood, M. M., \& Stifter, C. A. (1997). Compliance and noncompliance: The roles of maternal control and child temperament. Journal of Applied Developmental Psychology, 18(3), 411-428.

Caughy, M. O., Mills, B., Brinkley, D., \& Owen, M. T. (2018). Behavioral SelfRegulation, Early Academic Achievement, and the Effectiveness of Urban Schools for Low-Income Ethnic Minority Children. American journal of community psychology, 61(3-4), 372385.

Charlesworth, R. (2017). Understanding child development (10th ed). Boston, MA: Cengage Learning.

Chen, X., Chen, H., Wang, L., \& Liu, M. (2002). Noncompliance and childrearing attitudes as predictors of aggressive behaviour: A longitudinal study in Chinese children. International Journal of Behavioral Development, 26(3), 225-233.

De Falco, S., Emer, A., Martini, L., Rigo, P., Pruner, S., \& Venuti, P. (2014). Predictors of mother-child interaction quality and child attachment security in at-risk families. Frontiers in psychology, 5,898 .

Dennis, T. (2006). Emotional self-regulation in preschoolers: the interplay of child approach reactivity, parenting, and control capacities. Developmental psychology, 42(1), 84.

Edwards, C. P., \& Liu, W. (2002). Parenting toddler. In Bornstein, M. H. (Eds.), Handbook of parenting: volume 1 children and parenting. Mahwah, NJ: Psychology Press.
Feng, X., Hooper, E. G., \& Jia, R. (2017). From compliance to self-regulation: Development during early childhood. Social Development, 26(4), 981-995.

Grunzeweig, N., Stack, D. M., Serbin, L. A., Ledingham, J., \& Schwartzman, A. E. (2009). Effects of maternal childhood aggression and social withdrawal on maternal request strategies and child compliance and noncompliance. Journal of Applied Developmental Psychology, 30(6), 724-737.

Gurko, K. L. (2018). Socioeconomic Status Influence on Mothers' Interactions with Infants: Contributions to Early Infant Development (Doctoral dissertation) Retrieved from https://digitalcommons.usu.edu/etd/708 $0 /$

Hikmatunnisa, A. (2015) Hubungan antara Interaksi Ibu-Anak dan Pola Attachment (Studi pada Ibu-Anak Usia Toddler di Keluarga Miskin) (Undergraduate thesis). Retrieved from http://lib.ui.ac.id/detail?id=20412466\&1 okasi=lokal

Huaqing Qi, C., \& Kaiser, A. P. (2003). Behavior problems of preschool children from low-income families: Review of the literature. Topics in early childhood special education, 23(4), 188216.

Kalb, L. M., \& Loeber, R. (2003). Child disobedience and noncompliance: A review. Pediatrics, 111(3), 641-652.

Kochanska, G., \& Aksan, N. (1995). Motherchild mutually positive affect, the quality of child compliance to requests and prohibitions, and maternal control as correlates of early internalization. Child development, 66(1), 236-254.

Kochanska, G., \& Aksan, N. (2008). Child Compliance/Parent Discipline Project. Grazyna Kochanska Unpublished 
Papers. Archives of Department of Psychological and Brain Sciences, University of Iowa, Iowa City, IA.

Kochanska, G., Aksan, N. \& Carlson, J. J. (2005) Temperament, relationships, and young children's receptive cooperation with their parents. Developmental Psychology, 41, 648-660.

Kochanska, G., Coy, K. C., \& Murray, K. T. (2001). The development of selfregulation in the first four years of life. Child development, 72(4), 1091-1111.

Kok, R., Van IJzendoorn, M. H., Linting, M., Bakermans-Kranenburg, M. J., Tharner, A., Luijk, M. P., ... \& Tiemeier, $\mathrm{H}$. (2013). Attachment insecurity predicts child active resistance to parental requests in a compliance task. Child: care, health and development, 39(2), 277-287.

Kuczynski, L., \& Kochanska, G. (1990). Development of children's noncompliance strategies from toddlerhood to age 5. Developmental Psychology, 26(3), 398.

Kumar, R. (2011). Research Methodology: A Step by Step Guide for Beginners (3rd ed). New Delhi: SAGE Publications.

Maesyaroh, F. (2019) Anak 3 Tahun Keras dan Sulit Diatur [Online forum post]. Retrieved from https://rumahbungamatahari.wordpress. com/biro-psikologi-anak-dankeluarga/pernak-pernik-batita/anak-3tahun-keras-dan-sulit-diatur/

Newman, B. M., \& Newman, P. R. (2012). Development through life: $A$ psychosocial approach (12 $2^{\text {th }}$ ed). Belmont, CA: Cengage Learning.

Niken, G. (2017, Februari 8). 4 Alasan Mengapa Anak Susah Diatur Saat Menginjak Usia 2 Tahun [Online forum post]. Retrieved from http://nakita.grid.id/read/0210246/-4- alasan-mengapa-anak-susah-diatur-saatmenginjak-usia-2-tahun?page $=$ all

Papalia, D. E., \& Feldman, R. D. (2012). Experience human development (12th ed). New York, NY: McGraw-Hill.

Ramli, R. (2019, Juli 15). Standar Keluarga Miskin Jakarta: Pengeluaran Sebulan Kurang dari RP3,3 Juta. iNews.id. Retrieved from https://www-inewsid.cdn.ampproject.org/v/s/www.inews.i $\mathrm{d} / \mathrm{amp} /$ finance/makro/standar-keluargamiskin-jakarta-pengeluaran-sebulankurang-dari-rp33juta?usqp=mq331AQEKAFwAQ\%3D $\% 3 D \& a m p \_j s \_v=0.1 \#$

Santrock, J. (2011). Child development (13th ed.). New York, NY: McGraw-Hill Humanities.

SayangiAnak. (2016, November 30). Anak Usia 2-5 tahun Cenderung Keras Kepala, Kenali Kelebihan dan Tips Menghadapi si Kecil yang Keras Kepala [Online forum article]. Retrieved from http://sayangianak.com/anak-usia-2-5tahun-cenderung-keras-kepala-kenalikelebihan-dan-tips-menghadapi-sikecil-yang-keras-kepala/

Zulhaqqi, R. (2013, September 16). Mengatasi Batita 2 Tahun yang Sulit Diatur [Online forum discussion]. Retrieved from https://health.detik.com/konsultasipsikologi-anak-dan-remaja/d2359891/mengatasi-batita-2-tahunyang-sulit-diatur 